COSTA, Ilton Garcia da; DUARTE, Ronaldo Sergio. Responsabilidade do estado na efetivação dos direitos sociais: uma perspectiva pós-pandemia através da teoria da justiça de Rawls. Revista Eletrônica Direito e Política, Programa de Pós-Graduação Stricto Sensu em Ciência Jurídica da UNIVALI, Itajaí, v.16, n.2, $2^{\circ}$ quadrimestre de 2021. Disponível em: www.univali.br/direitoepolitica - ISSN 1980-7791.

\title{
RESPONSABILIDADE DO ESTADO NA EFETIVAÇÃO DOS DIREITOS SOCIAIS: UMA PERSPECTIVA PÓS-PANDEMIA ATRAVÉS DA TEORIA DA JUSTIÇA DE RAWLS
}

\author{
RESPONSIBILITY OF THE STATE IN THE ENFORCEMENT OF SOCIAL RIGHTS: $A$ \\ POST-PANDEMIC PERSPECTIVE THROUGH RAWLS THEORY OF JUSTICE
}

Ilton Garcia da Costa ${ }^{1}$

Ronaldo Sergio Duarte ${ }^{2}$

\section{RESUMO}

A Constituição Federal prevê extenso rol de direitos fundamentais sociais de responsabilidade do Estado. Sua concretização reverbera na dignidade humana, mas a disponibilização destes direitos demanda previsão orçamentário-financeira. O presente estudo tem por finalidade analisar o comportamento do Estado na concretização dos direitos sociais no contexto atual e pós-pandemia diante da necessidade da população e opções políticas que devem ser tomadas através da leitura da teoria da justiça de John Rawls. Trata-se de uma visão influenciada pelo impacto social e econômico gerado pela crise decorrente da pandemia. O método adotado é o dedutivo adotando-se a técnica de pesquisa bibliográfica na doutrina e revistas científicas. Pretende-se mostrar como a equidade rawlsiana pode influenciar, de forma igualitária, o comportamento do Estado para concretizar direitos fundamentais sociais através da construção de uma sociedade justa, concluindo-se que este resultado é possível.

PALAVRAS-CHAVE: Responsabilidade do Estado, Direitos Sociais Fundamentais, Pós-Pandemia, John Rawls, Teoria da Justiça.

\footnotetext{
${ }^{1}$ Doutor e Mestre em Direito - PUC SP Pontifícia Universidade de São Paulo, Mestre em Administração pelo Unibero, Pesquisador e Professor do Doutorado, Mestrado e Graduação da UENP Universidade Estadual do Norte do Paraná, Professor no latu sensu da Fundação Escola Superior do Ministério Público de Mato Grosso e da Universidade Federal do Mato Grosso - Uniselva, avaliador institucional e de cursos do INEP - MEC Ministério da Educação, Especialista em Formação Profissional - Alemanha, Especialista em Finança - FECAP. Foi Secretário Adjunto de Educação e Diretor Executivo do Instituto de Previdência do Município de Ourinhos SP, Membro do Comitê de Área da Fundação Araucária de Apoio à Pesquisa do Estado do Paraná, Membro do Comitê Avaliação da Lei de Incentivo ao Esporte do Estado de São Paulo, membro do Conselho Fiscal do Conpedi, Presidente da Comissão de Estágio e Vice Presidente da Comissão de Ensino Jurídico da OAB SP, coordenou o curso de Direito das Faculdade Anchieta SBC - Anhaguera, foi do Conselho Fiscal, Diretor e Coordenador do Curso de Direito da Unib - Universidade Ibirapuera, Diretor Superintendente de Planejamento e Controles do Banco Crefisul - BAQ. É membro do Conselho Editorial da Editora da UENP, É líder do GpCertos Grupo de Pesquisa em Constituição, Educação, Relações de Trabalho e Organização Sociais registrado no CNPq, Membro da E-Justicia Latinoamericana, Matemático, Advogado.

E-mail: iltongcosta@gmail.com e Iltoncosta@uenp.edu.br

2 Mestrando em Ciência Jurídica pela Universidade Estadual do Norte do Paraná - UENP, Jacarezinho - PR. Pós-graduado em Direito Constitucional e Direito Processual Civil pelo Damásio Educacional. Procurador Geral do Município de Marília, São Paulo. E-mail: ronaldoduarteadv@hotmail.com
} 
COSTA, Ilton Garcia da; DUARTE, Ronaldo Sergio. Responsabilidade do estado na efetivação dos direitos sociais: uma perspectiva pós-pandemia através da teoria da justiça de Rawls. Revista Eletrônica Direito e Política, Programa de Pós-Graduação Stricto Sensu em Ciência Jurídica da UNIVALI, Itajaí, v.16, n.2, $2^{\circ}$ quadrimestre de 2021. Disponível em: www.univali.br/direitoepolitica - ISSN 1980-7791.

\section{ABSTRACT}

The Federal Constitution provides for an extensive list of fundamental social rights under the responsibility of the State. Its realization reverberates in human dignity, but the availability of these rights demands budgetary-financial forecast. This study aims to analyze the behavior of the State in the realization of social rights in the current and post-pandemic context, in view of the population's needs and political options that must be taken through the reading of John Rawls' theory of justice. It is a view influenced by the social and economic impact generated by the crisis resulting from the pandemic. The method adopted is the deductive one, adopting the technique of bibliographic research in doctrine and scientific journals. It is intended to show how Rawlsian equity can equally influence the State's behavior to realize fundamental social rights through the construction of a just society, concluding that this result is possible.

KEY-WORKS: State Responsibility, Fundamental Social Rights, Post-Pandemic, John Rawls, Theory of Justice.

\section{INTRODUÇÃO}

A sociedade tinha como característica ser imparável, incessável. Mas de súbito, sofreu uma determinada ruptura não esperada, apesar de previsível por muitos cientistas da área da saúde.

A sociedade contemporânea e complexa, ávida por avanços tecnológicos sem preconceitos e desenvolvimento econômico sem sustentabilidade ambiental, está em ritmo de colapso estrutural e ético.

Trata-se de fenômeno universal. É tempo de recessão para a maioria dos segmentos econômicos, de contenção de despesas, enfim, de repaginar alguns conceitos que certamente afetarão a humanidade, mas sem aniquilar a condição essencial do homem para a vida em sociedade.

Fala-se em novo normal onde supõem os especialistas que teremos uma sociedade de princípios remodelados baseados no coletivo. Há quem diga que os valores humanos terão o elemento necessário para as relações sociais baseadas na solidariedade e fraternidade através do enfoque de questões necessariamente coletivas. 
COSTA, Ilton Garcia da; DUARTE, Ronaldo Sergio. Responsabilidade do estado na efetivação dos direitos sociais: uma perspectiva pós-pandemia através da teoria da justiça de Rawls. Revista Eletrônica Direito e Política, Programa de Pós-Graduação Stricto Sensu em Ciência Jurídica da UNIVALI, Itajaí, v.16, n.2, $2^{\circ}$ quadrimestre de 2021. Disponível em: www.univali.br/direitoepolitica - ISSN 1980-7791.

Outros, em esfera de atuação diversa, acreditam que o pacto global surgido ao final do século passado tende a mudar através de controle das finanças estatais, alterações na economia e respectivo sistema financeiro, modos de capitalismo e transformações sociais que mudam o estilo de vida de toda a população mundial.

Perguntas sem respostas surgem diante do quadro pandêmico e pós-pandemia. 0 Brasil possui uma população de milhões de pessoas que estão inseridas num universo de incertezas sob o ponto de vista social e econômico já que, apesar da posição econômica que ocupa no mundo, ostenta uma das maiores desigualdades sociais do planeta e ainda que a partilha de renda fosse igual, sem qualquer distinção de valores, ter-se-ia um país pobre.

Viver de incertezas ou de meras predições não é e nem pode ser a melhor solução para a efetivação de direitos sociais, em especial quando se percebe a ausência de recursos no orçamento estatal e incertezas políticas.

No cenário pós-pandemia a sociedade poderá não ser a mesma; já os problemas, além de persistirem, terão outra dimensão de gravidade e sob uma ótica de justiça como equidade não há melhor oportunidade do que esta em repensar acerca de uma sociedade justa e igualitária através da efetiva atuação estatal na efetivação dos direitos sociais.

Redimensionar o rearranjo da sociedade no clima pós-pandemia é um desafio para o Estado com suas responsabilidades de materialização da dignidade humana, mas certamente é uma circunstância que traz esperança para os brasileiros.

Por isso, refletir sobre o que está se passando poderá levar o país, através dos agentes do Estado, a repensar o pacto social dado pelos constituintes, despido de particularidades parciais, sem comprometimento com pessoas ou cargos, funções ou órgãos, elite ou plebeus, trabalhadores ou classe empresarial. Na verdade, parte-se para o pressuposto de cumprir o pacto através de um novo olhar sendo este o motivo de escolha do método dedutivo.

Obviamente que não se pretende tomar a fundo a totalidade do pensamento de Rawls neste estudo, bem como a solução do problema a ser discutido vai depender 
COSTA, Ilton Garcia da; DUARTE, Ronaldo Sergio. Responsabilidade do estado na efetivação dos direitos sociais: uma perspectiva pós-pandemia através da teoria da justiça de Rawls. Revista Eletrônica Direito e Política, Programa de Pós-Graduação Stricto Sensu em Ciência Jurídica da UNIVALI, Itajaí, v.16, n.2, $2^{\circ}$ quadrimestre de 2021. Disponível em: www.univali.br/direitoepolitica - ISSN 1980-7791.

de estudo empírico da responsabilidade atual do Estado do que da proposta da filosofia política adotada na teoria da justiça do jusfilósofo de Harvard.

Mas sem dúvida, o conceito formulado pela teoria da justiça - como uma das possibilidades viáveis - é importante para a efetivação dos direitos sociais póspandemia, em especial quando os recursos do orçamento público não alcançam todos na mesma medida.

\section{VÉU DA IGNORÂNCIA SOBRE OS EFEITOS DA PANDEMIA:}

No regime democrático o povo possui poder para decidir sobre questões relevantes ${ }^{3}$, inclusive, sobre a concretização dos direitos fundamentais por meio de processos políticos eleitorais de escolha dos representantes dos Poderes que ao final implantarão as políticas públicas relacionadas aos direitos sociais.

Depende de ação estatal efetiva. Parte do que era real, hoje é virtual; o abstrato da imaginação se tornou concreto, especialmente em tempos de isolamento social originado da pandemia.

Há uma interferência direta na vida das pessoas quando se fala sobre era digital, isto porque os atores protagonistas da sociedade da informação interagem através dos meios colocados à sua disposição de modo que este fato, associado à realidade virtual, se faz para implantar novos modelos de (participação na) democracia, de processos de inclusão social, influência digital que refletem no comportamento dos agentes políticos quanto à forma de governar, de administrar os negócios públicos.

A questão que se impõe neste contexto é perquirir o grau de ruptura ocorrida entre a sociedade pré e pós-pandemia a justificar um novo pacto social - ainda que em proporções menores se comparadas à proposta de John Rawls ${ }^{4}$ para um

\footnotetext{
3 Concepção sobre democracia segundo Aristóteles podemos encontrar em: GUARIGLIA, Osvaldo. Democracia: Origen, Concepto y Evolucion según Aristóteles. DOXA, Cuadernos de Filosofia del Derecho, 33 (2010). Disponível em <https://doxa.ua.es/article/view/2010-n33-democracia-origenconcepto-y-evolucion-segun-aristoteles $>$. Acesso em 23/06/2021.

${ }^{4}$ RAWLS, John. Uma teoria da Justiça. Tradução de Almiro Pisetta e Lenita M. R. Esteves. Editora Martins Fontes. 2000, p. 5.
} 
COSTA, Ilton Garcia da; DUARTE, Ronaldo Sergio. Responsabilidade do estado na efetivação dos direitos sociais: uma perspectiva pós-pandemia através da teoria da justiça de Rawls. Revista Eletrônica Direito e Política, Programa de Pós-Graduação Stricto Sensu em Ciência Jurídica da UNIVALI, Itajaí, v.16, n.2, $2^{\circ}$ quadrimestre de 2021. Disponível em: www.univali.br/direitoepolitica - ISSN 1980-7791.

neocontratualismo - mas que tenha alcance direto na efetivação dos direitos sociais e consequentemente na busca de uma sociedade mais igualitária no exato sentido da Constituição Federal em construí-la de forma livre, justa e solidária:

"Entre indivíduos com objetivos e propósitos díspares uma concepção partilhada de justiça estabelece os vínculos da convivência cívica; o desejo geral de justiça limita a persecução de outros fins. Pode-se imaginar uma concepção da justiça como constituindo a carta fundamental de uma associação humana bem-ordenada."

Portanto, na visão de Rawls, seria necessário um novo contrato social, agora, formada sob o véu da ignorância onde todos devem opinar por uma sociedade justa, onde se distribui bens e direitos através de regras e princípios de igualdade de oportunidade (princípio da igualdade de oportunidades) e levando em conta as diferenças de cada cidadão (princípio da diferença), mas sempre de uma forma que considere aqueles que estejam em posição de vulnerabilidade social.

Com uma sociedade que sofre com a carência de recursos estatais que deveriam estar diretamente vinculados a políticas públicas de qualidade, a ruptura social e econômica causada pela pandemia refletirá incisivamente no alcance de direitos sociais; a situação atual demonstrou uma sociedade digitalizada onde trabalho, serviços, lazer, comunicação, bancos e escola estão "on line".

Mas alimentação, renda decorrente de trabalho, segurança, saúde, proteção não são e não podem ser virtuais, demandam ação estatal efetiva que insere todos aqueles que estão no mesmo status social de proteção em um mínimo vital de existência digna conforme Costa e Campidelli5:

Deste modo, pode-se perceber que, desde o fim da Segunda Guerra Mundial, a preocupação com garantias mínimas aos indivíduos só vem crescendo. Hoje, o mundo percebe que a garantia deve ir além de fornecer alimento pra manter o ser humano vivo: é preciso dar condições básicas para o seu desenvolvimento.

\footnotetext{
${ }^{5}$ COSTA, Ilton Garcia, CAMPIDELLI, Laísa Fernanda. A diminuição da extrema pobreza, baseada em políticas públicas eficazes e garantia do mínimo existencial. Paz, constituição e políticas públicas - Vol. II. Organizadores: Ilton Garcia da Costa, Rogério Cangussu Dantas Cachichi, Teófilo Marcelo de ArêaLeão Júnior. Instituto Memória Editora \& Projetos Culturais. Centro de Estudos da Contemporaneidade, 2016.
} 
COSTA, Ilton Garcia da; DUARTE, Ronaldo Sergio. Responsabilidade do estado na efetivação dos direitos sociais: uma perspectiva pós-pandemia através da teoria da justiça de Rawls. Revista Eletrônica Direito e Política, Programa de Pós-Graduação Stricto Sensu em Ciência Jurídica da UNIVALI, Itajaí, v.16, n.2, $2^{\circ}$ quadrimestre de 2021. Disponível em: www.univali.br/direitoepolitica - ISSN 1980-7791.

No momento pós-pandemia, suspeita-se que, sob uma perspectiva ética e moral, uma nova sociedade se consolidará e o ideal seria que fosse sob o critério de equidade, de justiça social já que parcela relevante não estará mais na mesma posição anteriormente vivida.

Muitos irão depender de políticas públicas de responsabilidade do Estado para que os direitos sociais não sofram retrocesso social na sua manutenção o que implica na imperativa gestão igualitária dos recursos públicos destinados a esta parcela da sociedade na forma defendida por Francisco Secaf Silveira ${ }^{6}$ :

Como se disse, a consolidação de direitos implica na utilização de recursos ("direitos custam"). O que se demonstra é que a mera previsão desses direitos (ou de programas a eles relativos) no orçamento significa somente um pequeno passo ruma a sua concretização. O que de fato importa é o momento da execução orçamentária, no qual muitos programas ficam pelo caminho."

É neste viés que Elizabeth Martos $^{7}$ disserta sobre a eficiência na alocação de recursos financeiros do Estado sob a perspectiva jurídico-filosófica de John Rawls:

"O modo como determinada concepção de justiça faz a especificação de direitos e deveres fundamentais e define as parcelas distributivas fatalmente inclui nos problemas da eficiência, da coordenação e da estabilidade social, indiscutível, portanto, a influência dessas decisões na alocação de recursos para a realização das despesas públicas."

Por isso, a solução de equidade posta é no sentido de vendar os olhares de toda a sociedade e a partir daí formular um novo conceito de inclusão social para alcance de vida digna, justa e de qualidade.

Para isso, Rawls ${ }^{8}$ propõe uma sociedade forjada em situação de equidade, com princípios de justiça que assegurem as liberdades básicas e ao mesmo tempo

\footnotetext{
6 SILVEIRA, Francisco Secaf Alves. A concretização do Direito Financeiro: Os efeitos do contingenciamento na execução orçamentária. Dissertação em Direito Financeiro. Universidade de São Paulo - USP. 2014.

7 MARTOS, Elizabeth. O conteúdo jurídico do Princípio da Eficiência no Direito Financeiro. Dissertação de Mestrado em Direito. Faculdade de Direito da Universidade de São Paulo - USP. São Paulo, ano 2013.

${ }^{8}$ RAWLS, John. Uma teoria da Justiça. Tradução de Almiro Pisetta e Lenita M. R. Esteves. Editora Martins Fontes. 2000. p. 162.
} 
COSTA, IIton Garcia da; DUARTE, Ronaldo Sergio. Responsabilidade do estado na efetivação dos direitos sociais: uma perspectiva pós-pandemia através da teoria da justiça de Rawls. Revista Eletrônica Direito e Política, Programa de Pós-Graduação Stricto Sensu em Ciência Jurídica da UNIVALI, Itajaí, v.16, n.2, $2^{\circ}$ quadrimestre de 2021. Disponível em: www.univali.br/direitoepolitica - ISSN 1980-7791.

garante a diferença entre os indivíduos da sociedade, mas de modo que quem está em melhor condição, principalmente econômica, ajude o outro.

Ademais, os direitos sociais estão assegurados por princípios de justiça que Outeiro, Oliveira e Nascimento explicam:

A justiça deve permear todas estas esferas de atuação do Estado, para assegurar a justa distribuição de bens primários, que correspondem a um mínimo necessário para que um indivíduo possa viver com dignidade, ensejando uma forte correlação com o princípio da dignidade humana, que serve de fundamento da República9 ${ }^{9}$.

Com efeito, repensar a sociedade através de um novo modo de viver será tão elementar e importante quanto pensar na necessidade de se manter a geração atual e a vindoura - afirmando o indispensável pacto intergeracional - não relegando a sustentabilidade ambiental que permite o elemento vida, nem tampouco deixar de se aperceber que o mundo está sendo remodelado, esculpido em suas bases.

Tais mudanças devem gerar na sociedade o impacto contrário do que fora causado pela pandemia, isto é, com o efeito inverso no sentido de elevar o grau de civilidade na construção de uma sociedade mais altruísta, igualitária.

Neste sentido, como mencionado por Rawls ${ }^{10}$ quando trata da ideia principal da teoria da justiça:

\begin{abstract}
"Assim, devemos imaginar que aqueles que se comprometem na cooperação social escolhem juntos, numa ação conjunta, os princípios que devem atribuir os direitos e deveres básicos e determinar a divisão de benefícios sociais. Os homens devem decidir de antemão como devem regular suas reivindicações mútuas e qual deve ser a carta constitucional de fundação de sua sociedade."
\end{abstract}

\footnotetext{
9 OUTEIRO, Gabriel Moraes de; OLIVEIRA, Maria Cristina Cesar de; NASCIMENTO, Durbens Martins do. A justiça como equidade de Rawls e a igualdade de Amartya Sem: uma releitura na construção de um sistema de proteção de direitos fundamentais. Revista de Direito Público, Londrina, v. 11, n. 2, p. 47-81, ago. 2016. Disponível em https://www.readcube.com/articles/10.5433\%2F1980511x.2016v11n2p47>. Acesso em 22/06/2021.

10 RAWLS, John. Uma teoria da justiça. p. 12-13.
} 
COSTA, Ilton Garcia da; DUARTE, Ronaldo Sergio. Responsabilidade do estado na efetivação dos direitos sociais: uma perspectiva pós-pandemia através da teoria da justiça de Rawls. Revista Eletrônica Direito e Política, Programa de Pós-Graduação Stricto Sensu em Ciência Jurídica da UNIVALI, Itajaí, v.16, n.2, $2^{\circ}$ quadrimestre de 2021. Disponível em: www.univali.br/direitoepolitica - ISSN 1980-7791.

O Estado, por seus agentes, deve manter-se despido de tantos conceitos políticos e partidários, de nuances de vaidade no poder institucional concluindo, ao final, por um exercício mental de sobrepor à sociedade o véu da ignorância para um estado original mencionado na obra de Rawls e dali em diante estabelecer-se em situação de equidade.

\section{DIREITOS SOCIAIS A SEREM EFETIVADOS NO PÓS-PANDEMIA DIANTE DA RESPONSABILIDADE DO ESTADO:}

É cediço e manifesto na doutrina jurídica que os direitos sociais têm como destinatários principais os cidadãos que se encontrem em situação de vulnerabilidade social, fragilizados. São direitos prestacionais que dependem de atuação estatal positiva. Como bem tratado por Sarlet ${ }^{11}$ :

"Os direitos sociais a prestações, ao contrário dos direitos de defesa, não se dirigem à proteção da liberdade e igualdade abstrata, mas, sim, como já assinalamos alhures, encontramse intimamente vinculados às tarefas de melhoria, distribuição e redistribuição dos recursos existentes, bem como à criação de bens essenciais não disponíveis para todos os que deles necessitem".

A Constituição Federal traz um elenco expresso de modalidades de direitos sociais, tais como a educação, saúde, alimentação, trabalho, moradia, transporte, lazer e segurança, dentre outros.

O momento pós-pandemia tem sido chamado de "novo normal" no sentido de novo comportamento que possa garantir a sobrevivência, como bem mencionado por Schirato ${ }^{12}$.

\footnotetext{
11 SARLET Ingo Wolfgang. A eficácia dos direitos fundamentais: Uma teoria geral dos direitos fundamentais na perspectiva constitucional. 10 a edição, revista, atualizada e ampliada. Ed. Livraria do Advogado. Porto Alegre, 2010, p. 284.

12 Segundo Schirato, o novo normal, na verdade, seria a proposta de um novo padrão que possa garantir nossa sobrevivência. SCHIRATO, Maria Aparecida Rhein. Novo normal: entenda melhor esse conceito e seu impacto em nossas vidas (07/05/2020). Disponível na internet em: <https://www.insper.edu.br/noticias/novo-normal-conceito/>. Acesso em 19/06/2021.
} 
COSTA, Ilton Garcia da; DUARTE, Ronaldo Sergio. Responsabilidade do estado na efetivação dos direitos sociais: uma perspectiva pós-pandemia através da teoria da justiça de Rawls. Revista Eletrônica Direito e Política, Programa de Pós-Graduação Stricto Sensu em Ciência Jurídica da UNIVALI, Itajaí, v.16, n.2, $2^{\circ}$ quadrimestre de 2021. Disponível em: www.univali.br/direitoepolitica - ISSN 1980-7791.

Há vantagens nesta nova forma proposta que apesar de estar se consolidando, ainda não está totalmente definida. É fato ainda que as fronteiras físicas estão sendo transpostas pelo mundo digital e foram, de forma absolutamente visível, ampliadas; então, ocorrem as mudanças no modo de vida da sociedade moderna, do novo normal, de rotina comportamental de transição.

Por esta questão fundamental e particular modo de reflexão do novo estilo comportamental, o jusfilósofo Jurgen Habermas ${ }^{13}$ outrora questionou acerca dos novos horizontes éticos de modo a redefinir até mesmo a identidade do homem nas sociedades pluralistas:

"Os desenvolvimentos notórios e temidos da tecnologia genética afetam a imagem que havíamos construído de nós enquanto ser cultural da espécie, que é o homem, e para o qual parecia não haver alternativas."

A questão é que o avanço tecnológico que combina acesso da população à internet e aos serviços públicos de forma "on line", que provoca uma onda de prestação de serviços home office, que dá acesso à população ao ensino, entre outras, traduz uma nova forma de inclusão social, aumentando eficazmente a participação da sociedade em tudo quanto diz respeito às instituições e à própria vida.

De outro lado, da mesma forma que a tecnologia digital alavancada pela pandemia proporcionou que se efetivassem alguns direitos sociais cujos custos são diminuídos para o Estado - ou ao menos devem diminuir - grande parcela dos cidadãos enfrentarão a crise social e econômica na perda do emprego formal, na forma de trabalho que poderá restar ultrapassada, na falta de renda que não é gerada da mesma forma como antes e na falta de qualificação daquele cidadão que perdeu o emprego entre tantas outras situações adversas.

Enfim, que futuro de normalidade será este onde os direitos sociais poderão sofrer retrocesso social na medida em que o Estado, responsável pela sua efetivação, não obter o êxito esperado em políticas públicas inovadoras a um número elevadíssimo de pessoas sem condições de manter suas famílias e a si próprio?

13 HABERMAS, Jurgen. O futuro da natureza humana. A caminho de uma eugenia liberal? Tradução de Karina Jannini. São Paulo: Martins Fontes Editora. 2004. p. 56. 
COSTA, Ilton Garcia da; DUARTE, Ronaldo Sergio. Responsabilidade do estado na efetivação dos direitos sociais: uma perspectiva pós-pandemia através da teoria da justiça de Rawls. Revista Eletrônica Direito e Política, Programa de Pós-Graduação Stricto Sensu em Ciência Jurídica da UNIVALI, Itajaí, v.16, n.2, $2^{\circ}$ quadrimestre de 2021. Disponível em: www.univali.br/direitoepolitica - ISSN 1980-7791.

O desafio requer criatividade do Estado quanto a criar políticas públicas após detectar as mazelas que impregnarão a sociedade brasileira tão cravejada de injustiça e exclusão social.

Um dos problemas a serem enfrentados pós-pandemia é de certo a equalização das despesas e das receitas públicas sendo que estas devem ser direcionadas, agora em maior intensidade, às políticas públicas na área da educação - e aqui englobam cursos técnicos ou de formação profissional, além de especializações nas universidades públicas que digam respeito aos novos rumos da sociedade da saúde tal o nível de deficiência de recursos humanos revelado na pandemia, embora o Sistema Único de Saúde tenha demonstrado boas condições gerais de atendimento à população, e de geração de renda mínima.

A questão é que o endividamento público agravado com a pandemia já está causando grande impacto nas finanças públicas de modo a surrupiar o exercício dos direitos sociais, mormente se for levado em conta que o número de pessoas em situação de vulnerabilidade social aumentou e tende a aumentar ainda mais por conta do tempo necessário para a volta da normalidade.

Ainda, reportando-se ao ensino de Rawls, um dos pressupostos da justiça como equidade é o fato da escassez moderada de recursos, isto é, a totalidade dos recursos é menor que a demanda da sociedade e a vida no futuro vai depender de escolhas públicas acertadas. Não basta administrar para as próximas eleições, mas para toda uma geração que se aproxima.

Nestas condições, Oliveira e Ferreira ${ }^{14}$ argumentam sobre a necessidade de responsabilidade na gestão fiscal a fim de que as políticas públicas alcancem o cidadão:

"Ora, se os cidadãos, com seus recursos vertidos para o sistema, financiam a atividade estatal, é mais do que obrigação do Estado, portanto, que a contrapartida seja ofertada com a concretização de políticas públicas essenciais

\footnotetext{
${ }^{14}$ OLIVEIRA, Cláudio Ladeira, FERREIRA, Francisco Gilney Bezerra de Carvalho. O Orçamento Público no Estado Constitucional Democrático e a Deficiência Crônica na Gestão das Finanças Públicas no Brasil. Saúde, Ética e Justiça, vol. 38, n. 76, p. 183-212, ago. 2017.
} 
COSTA, Ilton Garcia da; DUARTE, Ronaldo Sergio. Responsabilidade do estado na efetivação dos direitos sociais: uma perspectiva pós-pandemia através da teoria da justiça de Rawls. Revista Eletrônica Direito e Política, Programa de Pós-Graduação Stricto Sensu em Ciência Jurídica da UNIVALI, Itajaí, v.16, n.2, $2^{\circ}$ quadrimestre de 2021. Disponível em: www.univali.br/direitoepolitica - ISSN 1980-7791.

ao povo, fazendo-se o uso responsável dos recursos públicos por meio da adequada gestão orçamentária.'

Vale perquirir quais serão as escolhas do Estado responsável - e garantidor - para impedir o retrocesso quanto aos direitos sociais, bem como para assegurar que o momento pós-pandêmico atinja o menor número de pessoas, em especial porque levadas a um patamar de carência econômica que não Ihes permita o exercício de um mínimo existencial sem depender, necessariamente, de efetiva ação estatal.

Garantir o exercício dos direitos sociais das pessoas em vulnerabilidade é um desafio manifesto na medida em que a sociedade contemporânea - pluralista por excelência - possui necessidades diversas.

Mas o que converge para o norte a ser seguido pelo Estado são as ações que garantam a dignidade humana; e tudo isto vai depender do quanto de esforço criativo e de recursos orçamentário-financeiros ${ }^{15}$ o Estado vai direcionar para a concretização desta tarefa através das políticas públicas determinantes:

"Por tal feita, a insuficiência de recursos orçamentários decorrentes de escassa arrecadação tributária não serve como mote justificador de ausência de cobertura dos direitos fundamentais, pois suprimiria a garantia de proibição de retrocesso."

A ação do Estado em garantir a normalidade no novo comportamento de vida póspandemia vai existir na mesma medida em que os agentes políticos se esforçarem, legitimamente, para que se inclua na agenda pública tão somente a efetivação dos direitos sociais prestacionais independentemente da agenda política, dissociada do interesse nas urnas, o que faz incluir o desejo de justiça dos membros da sociedade que já foram cobertos - hipoteticamente - por um véu da ignorância causado, aprioristicamente, pela pandemia do coronavírus.

Portanto, o mínimo existencial deve ser a meta do Estado a qualquer tempo; no momento pós-pandemia muito mais. Veja-se, como exemplo, o alerta da ONU feito

15 MARQUES de Azevedo, E.; BARÇANTE de Almeida, G. e ALVARENGA Portes, P. O Mito da Teoria da Reserva do Possível: os impasses do orçamento público para o desenvolvimento dos direitos sociais. Direito e Desenvolvimento, v. 4, n. 8, p. 33-59, 5 jun. 2017. 
COSTA, IIton Garcia da; DUARTE, Ronaldo Sergio. Responsabilidade do estado na efetivação dos direitos sociais: uma perspectiva pós-pandemia através da teoria da justiça de Rawls. Revista Eletrônica Direito e Política, Programa de Pós-Graduação Stricto Sensu em Ciência Jurídica da UNIVALI, Itajaí, v.16, n.2, $2^{\circ}$ quadrimestre de 2021. Disponível em: www.univali.br/direitoepolitica - ISSN 1980-7791.

em 2020 no sentido de que 49 milhões de pessoas poderiam ser levadas à pobreza em razão da pandemia ${ }^{16}$.

Vale apontar ainda importante estudo da OXFAM ${ }^{17}$ - Oxford Committee for Famine Relief - organização mundial de direitos humanos que busca soluções nos problemas de pobreza, desigualdade e injustiça, no sentido de que:

"A pandemia da COVID-19 somou-se a essa combinação já tóxica de fatores, aumentando rapidamente as taxas de pobreza e fome em todo o país. As medidas de distanciamento social adotadas para conter a propagação do coronavírus e evitar o colapso do sistema público de saúde agravaram a crise econômica. Milhões de trabalhadores mais pobres, com poucos recursos em poupança e acesso limitado a benefícios, perderam seus empregos ou renda da noite para o dia."

Estudos como o supra citado revelam a necessidade imperiosa do Estado Brasileiro em detectar agendas referentes aos problemas de gravidade social que já estavam arraigados na população brasileira, agravados pelos efeitos da pandemia, e por consequência implantar as políticas públicas que garantam, no mínimo, a existência digna.

\section{MÍNIMO EXISTENCIAL E A DE ESCASSEZ DOS RECURSOS PÚBLICOS:}

Não há vida em sociedade sem um mínimo de direitos que possam ser exercidos pelo cidadão. Não há boa gestão pública de responsabilidade do Estado sem que antes venha a concretização dos direitos fundamentais que outrora tinha como

\footnotetext{
${ }^{16}$ Segundo António Guterres, secretário-geral das Nações Unidas, "Este ano, cerca de 49 milhões de pessoas podem cair na pobreza extrema devido à crise da COVID-19. O número de pessoas expostas a uma grave insegurança alimentar e nutricional vai crescer rapidamente. A queda de um ponto percentual no Produto Interno Bruto global significa mais 700 mil crianças raquíticas". (15/07/2020). Disponível na internet: < https://nacoesunidas.org/pandemia-pode-ampliar-fome-ejogar-49-milhoes-de-pessoas-na-pobreza-extrema-alerta-onu/>. Acesso em 24/06/2021.

17 "O Vírus da Fome: como o coronavírus está potencializando a fome em um mundo faminto", relatório lançado pela OXFAM. Disponível na internet em: <https://d2v21prk53tg5m.cloudfront.net/wp-content/uploads/2020/07/Informe-Virus-da-Fomeembargado-FINAL-1.pdf> (23/07/2020). Acesso em 24/06/2021.
} 
COSTA, Ilton Garcia da; DUARTE, Ronaldo Sergio. Responsabilidade do estado na efetivação dos direitos sociais: uma perspectiva pós-pandemia através da teoria da justiça de Rawls. Revista Eletrônica Direito e Política, Programa de Pós-Graduação Stricto Sensu em Ciência Jurídica da UNIVALI, Itajaí, v.16, n.2, $2^{\circ}$ quadrimestre de 2021. Disponível em: www.univali.br/direitoepolitica - ISSN 1980-7791.

concepção a de ser 'interesse público', conceito que foi reformulado segundo Gustavo Binenbojm ${ }^{18}$ :

"Toda a sistematização dos poderes e deveres da Administração Pública passa a ser traçada a partir dos lineamentos constitucionais pertinentes, com especial ênfase no sistema de direitos fundamentais e nas normas estruturantes do regime democrático, à vista de sua posição axiológica central e fundante no contexto do Estado democrático de direito."

O mínimo vital compreende parcela indelegável da ação do Estado na atividade empreendedora dos direitos sociais devendo abarcar um teto e alimento para sua sobrevivência. Traz dignidade a qualquer pessoa do país mais fragilizado social e economicamente do mundo.

Neste viés, como bem exposto por Suxberger e Lemos ${ }^{19}$ :

\begin{abstract}
"Por isso, a compreensão da dignidade como razão fundante da entrega de direitos fundamentais, tomados como mais básicos, sobretudo a permitir a realização desses poderes e direitos ao indivíduo, destinatário último do sistema jurídico. Do contrário, ter-se-á um Estado que não cumpre suas funções essenciais e, o que é mais grave, afasta-se das razões que justificam sua própria existência".
\end{abstract}

Ter saúde é por demais importante, mas não se pode esquecer que o conceito de saúde, segundo definido pela Organização Mundial de Saúde ${ }^{20}$, engloba não só a ausência de doenças ou moléstias, mas também um estado de bem estar físico e mental.

A Constituição Federal estabelece claramente as regras de competência de cada ente estatal instituir e cobrar seus respectivos tributos, em especial os impostos. É a competência tributária referente ao poder arrecadador do Estado. A questão

\footnotetext{
18 BINENBOJM, Gustavo. Uma teoria do Direito Administrativo. Direitos Fundamentais, Democracia e Constitucionalização. $3^{a}$ edição revista e atualizada. Rio de Janeiro: Renovar, 2014, p. 38.

19 SUXBERGER, Antonio Henrique Graciano, LEMOS, Rubin. O orçamento público como instrumento de concretização da dignidade da pessoa humana. Revista Jurídica da Presidência Brasília, v. 22 n. 126 Fev./Maio 2020, p. 88-112. Disponível na internet em $<$ https://revistajuridica.presidencia.gov.br/index.php/saj/article/view/1878>. Acesso em 30/05/2021.

20 Conceito formulado pela OMS; disponível na internet < https://saudebrasil.saude.gov.br/euquero-me-exercitar-mais/o-que-significa-ter-saude>. Acesso em 28/06/2021.
} 
COSTA, IIton Garcia da; DUARTE, Ronaldo Sergio. Responsabilidade do estado na efetivação dos direitos sociais: uma perspectiva pós-pandemia através da teoria da justiça de Rawls. Revista Eletrônica Direito e Política, Programa de Pós-Graduação Stricto Sensu em Ciência Jurídica da UNIVALI, Itajaí, v.16, n.2, $2^{\circ}$ quadrimestre de 2021. Disponível em: www.univali.br/direitoepolitica - ISSN 1980-7791.

nodal é após o ingresso das rendas públicas nos cofres, ou seja, como se dará a destinação dos recursos para se garantir um bem estar físico e mental, um mínimo vital que represente a dignidade da vida humana, bem supremo de responsabilidade do Estado.

E neste sentido, vale a proposta de melhor utilização dos recursos públicos e respectiva distribuição em atenção ao princípio da diferença adotado por Rawls, o que é lembrado por Elizabeth Martos ${ }^{21}$ :

"A leitura da obra de J. Rawls permite inferirmos que a despesa pública funciona como um elemento corretor de desigualdade, ou melhor, nivelador de condições sócioeconômicas, em que se extrai que os menos afortunados pelas condições de nascimento independente de seus méritos tem prioridade no acesso aos recursos públicos."

Neste sentido, o texto constitucional previu o chamado pacto federativo donde se extrai que as receitas arrecadadas por cada ente a ele pertencem para cumprir o papel de garantidor dos direitos sociais devendo referida ação ser responsável (Lei de Responsabilidade Fiscal, art. $1^{\circ}, \S 1^{\circ}$ ).

Mas o pacto federativo também estabelece regras de redistribuição das receitas públicas de modo que a União destina parte dos tributos arrecadados aos Estados e Municípios e aqueles a estes. Sempre do ente de maior envergadura para o de menor, nunca o contrário conforme doutrina de André Portella e Jéssica de Jesus ${ }^{22}$ :

\footnotetext{
"Dessa forma, o ente federativo com maior capacidade de arrecadação repassa recursos para os entes menores, para que estes possam cumprir com as obrigações constitucionais estabelecidas."
}

Questão importante para garantir as políticas públicas de efetivação dos direitos sociais, portanto, é investigar a execução orçamentária pelo Estado na consecução destes direitos, isto é, se os recursos previstos originariamente no orçamento público estão sendo aplicados, em sua integralidade, de forma positiva, através da

\footnotetext{
${ }^{21}$ MARTOS, Elizabeth. O conteúdo jurídico do Princípio da Eficiência no Direito Financeiro, p. 98. 22" PORTELLA, André Alves, JESUS, Jessica Ferreira de. Federalismo Fiscal e Descentralização Administrativa: A deficiência de autonomia dos Municípios do Baixo Sul da Bahia na promoção de ações de saúde. Revista de Direito da Cidade, vol. 10, no 2, p. 834-861. Disponível em <https://www.e-publicacoes.uerj.br/index.php/rdc/article/view/31563>. Acesso em 17/06/2021.
} 
COSTA, IIton Garcia da; DUARTE, Ronaldo Sergio. Responsabilidade do estado na efetivação dos direitos sociais: uma perspectiva pós-pandemia através da teoria da justiça de Rawls. Revista Eletrônica Direito e Política, Programa de Pós-Graduação Stricto Sensu em Ciência Jurídica da UNIVALI, Itajaí, v.16, n.2, $2^{\circ}$ quadrimestre de 2021. Disponível em: www.univali.br/direitoepolitica - ISSN 1980-7791.

atuação governamental já que esta, em princípio, é a finalidade pela qual o Estado existe.

Precisamente, aos agentes políticos é dado poder para representar e agir em favor do povo, executando ações em busca do bem estar social e não individual, isto é, agindo nos exatos limites do mandato conferido a ele.

Aqui entra um dado empírico, especificamente o resultado da análise do Plano Plurianual de 2016/2019, do Poder Executivo Federal pelo Tribunal de Contas da União através do Processo de Contas do Governo do exercício de 2019, tendo como relator o Ministro Bruno Dantas ${ }^{23}$.

Dentre os vários indicadores demonstrados no relatório que culminou na apresentação de Parecer Prévio favorável às Contas do Governo, se observou que:

"A partir da análise dos principais índices de desenvolvimento econômico e social, verifica-se que o Brasil, no período do PPA 2016-2019, não foi capaz de retomar a evolução nos indicadores. O país vem perdendo posições nos diversos rankings, uma vez que os valores médios para os demais países do mundo continuam crescendo" 24 .

Isto quer dizer que os direitos sociais, em especial, a segurança, a educação e programas de moradia, estão sofrendo um retrocesso social. Neste teor, o mencionado relatório do TCU nas Contas do Governo cita que o Índice de Desenvolvimento Humano - IDH - estagnou a partir de 2013 no Brasil enquanto que nos demais países cresceu de forma manifesta 25.

Também demonstra a baixa densidade de concretização de direitos sociais e desenvolvimento econômico o relatório do Banco Mundial também citado no aludido relatório do Parecer Prévio do TCU através do projeto Indicadores de Governança Mundiais (WGI - Worldwide Governance Indicators) que detectou piora

\footnotetext{
23 TC 018.177/2020-4, Processo das Contas do Governo de responsabilidade do Presidente da República Jair Bolsonaro cujo parecer prévio foi da relatoria do Ministro Bruno Dantas, do TCU.

24 Trecho do Parecer Prévio do TCU já citado.

25 Trecho do Parecer Prévio do TCU já citado: "Porém, a partir de 2013, o país deixou de apresentar evolução no índice geral e de educação e houve declínio no componente da renda. O que se verifica no gráfico é que, enquanto o IDH brasileiro estagnou a partir de 2013, o restante do mundo, incluindo os países em desenvolvimento, manteve seu crescimento".
} 
COSTA, IIton Garcia da; DUARTE, Ronaldo Sergio. Responsabilidade do estado na efetivação dos direitos sociais: uma perspectiva pós-pandemia através da teoria da justiça de Rawls. Revista Eletrônica Direito e Política, Programa de Pós-Graduação Stricto Sensu em Ciência Jurídica da UNIVALI, Itajaí, v.16, n.2, $2^{\circ}$ quadrimestre de 2021. Disponível em: www.univali.br/direitoepolitica - ISSN 1980-7791.

significativa dos índices de ação governamental, tendo como fator a ausência de qualidade na implantação das políticas públicas ${ }^{26}$.

O relatório do Parecer Prévio aponta ainda, entre outros resultados, que a política pública referente à renda ofertada às famílias e indivíduos em situação de vulnerabilidade social e pessoal através do Sistema Único de Assistência Social apresentou desempenho insatisfatório ${ }^{27}$ :

"[...] o que significa que a camada mais pobre e vulnerável da população está, de fato, recebendo menos e piores serviços socioassistenciais, complementares às transferências de renda, o que contribui potencialmente para o aumento da pobreza multidimensional".

Neste viés, a tendência poderá ser a falência das políticas públicas inerentes aos direitos sociais prestacionais a considerar o desempenho da ação governamental no quadriênio 2016-2019; considerando ainda que os efeitos da pandemia no contexto econômico-social se caracterizam por pontos negativos, esperar que as profecias se cumpram seria o mais lógico e mais próximo da realidade, inclusive, diante da escassez dos recursos orçamentários e financeiros.

Em outras palavras, sem recursos não há incremento das políticas públicas de efetividade dos direitos sociais.

Todavia, a justiça como equidade deve ser buscada visto que países em pior condição socioeconômica vivida outrora (Coréia do Sul, Japão, Rússia, etc) saíram ou estão saindo de uma condição de baixa densidade na concretização dos direitos para a adoção de políticas públicas na educação, saúde, profissionalização, geração de empregos e rendas que constituem um processo de evolução social e desenvolvimento econômico tão sonhado pela população brasileira.

\footnotetext{
26 Trecho do Parecer Prévio do TCU já citado: "Para essas duas dimensões de resultado, no período do PPA 2016-2019, com base no último dado dos indicadores de 2018, houve piora significativa no desempenho, de $-0,17$ para $-0,45$. Por isso, o Brasil cai no ranking de 46,63 para 36,06 na efetividade governamental, e de $-0,21$ para - $-0,31$ na qualidade regulatória, com queda do indicador de 46,63 para 39,90".

27 TC 018.177/2020-4, Processo das Contas do Governo apreciado pelo Tribunal de Contas da União.
} 
COSTA, Ilton Garcia da; DUARTE, Ronaldo Sergio. Responsabilidade do estado na efetivação dos direitos sociais: uma perspectiva pós-pandemia através da teoria da justiça de Rawls. Revista Eletrônica Direito e Política, Programa de Pós-Graduação Stricto Sensu em Ciência Jurídica da UNIVALI, Itajaí, v.16, n.2, $2^{\circ}$ quadrimestre de 2021. Disponível em: www.univali.br/direitoepolitica - ISSN 1980-7791.

Assim, para assegurar o mínimo existencial diante da escassez de recursos públicos, Ricardo Gaspar $^{28}$ apresenta um plano bastante convincente:

"Em suma, talvez uma das tarefas mais importantes que desafiam o futuro humano seja recuperar o sentido do público, a esfera coletiva da existência, o que impõe reformar o Estado, dotando-o de transparência, mecanismos de gestão participativa e descentralizada e do reforço dos instrumentos de regulação da economia e do mercado".

Portanto, é cediço que os recursos orçamentários do Estado servem para cumprir o papel consagrado no pacto social quanto aos direitos fundamentais sendo certo dizer que a escassez passa a ser justificativa para o não cumprimento dos objetivos delineados nas políticas públicas.

Todavia, não pode ser esta a conduta do gestor, em especial quando levando em conta o senso de justiça e a base da igualdade na obra de Rawls uma vez que a postura do gestor público na Administração Pública complexa a qual vivemos deve ser a mais criativa e igualitária possível, desvencilhando-se da política de governo - emperrada por conceitos patrimonialistas - para uma verdadeira política de estado motivada pela busca do interesse público consubstanciado em direito fundamental social, exclusivamente.

\section{CONSIDERAÇÕES FINAIS}

As análises acima constatam que os problemas sociais estão identificados, revelados manifestamente pelos indicadores sociais apontados pelo controle externo dos atos governamentais, sem contar com os demais estudos de instituições multilaterais. O país coleciona severas dificuldades, problemas sociais e econômicos para uma população que espera avidamente por uma postura proativa do Estado, espera-se por dias melhores.

28 GASPAR, Ricardo Carlos. A trajetória da economia mundial: da recuperação do pós-guerra aos desafios contemporâneos. Cadernos Metrópole, PUC. São Paulo, v. 17, n. 33, pp. 265-296, maio 2015. 
COSTA, Ilton Garcia da; DUARTE, Ronaldo Sergio. Responsabilidade do estado na efetivação dos direitos sociais: uma perspectiva pós-pandemia através da teoria da justiça de Rawls. Revista Eletrônica Direito e Política, Programa de Pós-Graduação Stricto Sensu em Ciência Jurídica da UNIVALI, Itajaí, v.16, n.2, $2^{\circ}$ quadrimestre de 2021. Disponível em: www.univali.br/direitoepolitica - ISSN 1980-7791.

O aguardado estado de normalidade deve alcançar a todos, sem distinção de classe social, em especial sem anomalias sociais ou econômicas nos exatos termos da obra de John Rawls.

O desenvolvimento econômico do país deve voltar ao rumo que se pretendia antes da pandemia, mas as escolhas e opções políticas devem ter como meta os direitos sociais, o interesse público da comunidade em situação de vulnerabilidade.

A possibilidade para a retomada do curso na efetivação dos direitos sociais existe, mas requer trabalho hercúleo a partir da vontade do Estado aliado à força e dignidade que tem a legislação séria, despida de interesses que não seja o bem comum e o desenvolvimento sustentável.

Não se pode esquecer que o pacto social impresso pela Constituição Federal foi determinante para o início da construção de uma sociedade livre, justa e solidária, na real concepção de um estado original rawlsiano com garantias dos direitos e liberdades básicas.

O relatório do Parecer Prévio das Contas do Governo do ano de 2019 emitido pelo Tribunal de Contas da União foi capaz de expedir inúmeras recomendações encaminhadas ao Poder Executivo, tendo detectado várias metas não alcançadas o que significa dizer que o mapeamento das necessidades e dos problemas estão diagnosticados e claramente demonstrados a merecerem total atenção dos agentes políticos.

Significa dizer que há caminho certo e determinado a seguir sem que dele se desvie no sentido de atingir o objetivo final. Sabe-se que os direitos fundamentais servem para a concretização da dignidade humana.

Os indicadores de políticas públicas e de eficiência na gestão pública servem para balizar as ações governamentais futuras de modo a elevar os índices de atendimento e concretização dos direitos sociais de responsabilidade do Estado.

A partir do momento em que se interfira nos direitos sociais por conta da omissão ou ausência de políticas públicas determinantes oriundas do Estado, inclusive por incorrer em manifesto retrocesso social, não há outro remédio senão o de 
COSTA, Ilton Garcia da; DUARTE, Ronaldo Sergio. Responsabilidade do estado na efetivação dos direitos sociais: uma perspectiva pós-pandemia através da teoria da justiça de Rawls. Revista Eletrônica Direito e Política, Programa de Pós-Graduação Stricto Sensu em Ciência Jurídica da UNIVALI, Itajaí, v.16, n.2, $2^{\circ}$ quadrimestre de 2021. Disponível em: www.univali.br/direitoepolitica - ISSN 1980-7791.

escancarar os sintomas e os efeitos colaterais do ato administrativo ilegítimo a fim de que seja contido pelos órgãos constitucionalmente incumbidos desta singular tarefa, sem prejuízo de expor à sociedade os malefícios da ausência dos direitos sociais a verdadeiro titular deste direito.

Assim e só com políticas responsáveis, a responsabilidade do Estado na efetivação dos direitos sociais será cumprida de acordo com os mandamentos constitucionais.

\section{REFERÊNCIAS DAS FONTES CITADAS}

AZEVEDO, Eder Marques de; ALMEIDA, Gustavo Barçante de; PORTES, Paola Alvarenga. O Mito da Teoria da Reserva do Possível: os impasses do orçamento público para o desenvolvimento dos direitos sociais. Direito e Desenvolvimento, v. 4 , n. 8, p. 33-59, 2017.

BINENBOJM, Gustavo. Uma teoria do Direito Administrativo. Direitos Fundamentais, Democracia e Constitucionalização. $3^{a}$ edição revista e atualizada. Rio de Janeiro: Renovar, 2014, p. 38.

COSTA, IIton Garcia da; REZENDE, Rita de Cassia. Liberdade, Igualdade e Democracia. Revista Em Tempo (Online), v. 18, p. 272-299, 2019.

COSTA, IIton Garcia; GOES, Winnicius Pereira . A Diretiva 2014/24/UE como Guia de Contratualizações Sustentáveis de Políticas Públicas Sociais. Novos Estudos Jurídicos (Online), v. 21, p. 656-690, 2016.

COSTA, Ilton Garcia da; TOSAWA, Suelyn; CACHICHI, Rogério Cangussu D. . Denationalization Production and Social Exclusion in Labor Economics Globalized. Nomos (Fortaleza), v. 39, p. 149-162, 2019

COSTA, Ilton Garcia, CAMPIDELLI, Laísa Fernanda. A diminuição da extrema pobreza, baseada em políticas públicas eficazes e garantia do mínimo existencial. Paz, constituição e políticas públicas - Vol. II. Organizadores: Ilton Garcia da Costa, Rogério Cangussu Dantas Cachichi, Teófilo Marcelo de Arêa Leão Júnior. Instituto Memória Editora \& Projetos Culturais. Centro de Estudos da Contemporaneidade, 2016.

GASPAR, Ricardo Carlos. A trajetória da economia mundial: da recuperação do pós-guerra aos desafios contemporâneos. Cadernos Metrópole, PUC. São Paulo, v. 17 , n. 33, pp. 265-296, maio 2015. 
COSTA, Ilton Garcia da; DUARTE, Ronaldo Sergio. Responsabilidade do estado na efetivação dos direitos sociais: uma perspectiva pós-pandemia através da teoria da justiça de Rawls. Revista Eletrônica Direito e Política, Programa de Pós-Graduação Stricto Sensu em Ciência Jurídica da UNIVALI, Itajaí, v.16, n.2, $2^{\circ}$ quadrimestre de 2021. Disponível em: www.univali.br/direitoepolitica - ISSN 1980-7791.

GUARIGLIA, Osvaldo. Democracia: Origen, Concepto y Evolucion según Aristóteles. DOXA, Cuadernos de Filosofia del Derecho, 33 (2010). Disponível em <https://doxa.ua.es/article/view/2010-n33-democracia-origen-concepto-yevolucion-segun-aristoteles>. Acesso em 23 abr2021.

HABERMAS, Jurgen. O futuro da natureza humana. A caminho de uma eugenia liberal? Tradução de Karina Jannini. São Paulo: Martins Fontes Editora. 2004.

KUKATHAS, Chandran; PETTIT, Philip. Rawls: uma teoria da justiça e seus críticos. Lisboa: Gadiva, 1995.

MARQUES de Azevedo, E.; BARÇANTE de Almeida, G. e ALVARENGA Portes, P. O Mito da Teoria da Reserva do Possível: os impasses do orçamento público para o desenvolvimento dos direitos sociais. Direito e Desenvolvimento, v. 4, n. 8, p. 33-59, 2017.

MARTOS, Elizabeth. O conteúdo jurídico do Princípio da Eficiência no Direito Financeiro. Dissertação de Mestrado em Direito. Faculdade de Direito da Universidade de São Paulo - USP. São Paulo, ano 2013

OLIVEIRA, Cláudio Ladeira, FERREIRA, Francisco Gilney Bezerra de Carvalho. O Orçamento Público no Estado Constitucional Democrático e a Deficiência Crônica na Gestão das Finanças Públicas no Brasil. Saúde, Ética e Justiça, vol. 38, n. 76, p. 183-212, ago. 2017.

ONU: Pandemia pode ampliar fome e jogar 49 milhões na pobreza extrema. Disponível na internet: <https://nacoesunidas.org/pandemia-pode-ampliar-fomee-jogar-49-milhoes-de-pessoas-na-pobreza-extrema-alerta-onu/>.

OUTEIRO, Gabriel Moraes de; OLIVEIRA, Maria Cristina Cesar de; NASCIMENTO, Durbens Martins do. A justiça como equidade de Rawls e a igualdade de Amartya Sem: uma releitura na construção de um sistema de proteção de direitos fundamentais. Revista de Direito Público, Londrina, v. 11, n. 2, p. 47-81, ago. 2016. Disponível em https://www.readcube.com/articles/10.5433\%2F1980511x.2016v11n2p47>. Acesso em 22 abr2021.

OXFAM. Disponível na internet em: <https://d2v21prk53tg5m.cloudfront.net/wpcontent/uploads/2020/07/Informe-Virus-da-Fome-embargado-FINAL-1.pdf>.

PORTELLA, André Alves, JESUS, Jessica Ferreira de. Federalismo Fiscal e Descentralização Administrativa: A deficiência de autonomia dos Municípios do Baixo Sul da Bahia na promoção de ações de saúde. Revista de Direito da Cidade, vol. 10, no 2. P. 834-861.

RAWLS, John. Uma teoria da Justiça. Tradução de Almiro Pisetta e Lenita M. R. Esteves. Editora Martins Fontes. 2000. 
COSTA, Ilton Garcia da; DUARTE, Ronaldo Sergio. Responsabilidade do estado na efetivação dos direitos sociais: uma perspectiva pós-pandemia através da teoria da justiça de Rawls. Revista Eletrônica Direito e Política, Programa de Pós-Graduação Stricto Sensu em Ciência Jurídica da UNIVALI, Itajaí, v.16, n.2, $2^{\circ}$ quadrimestre de 2021. Disponível em: www.univali.br/direitoepolitica - ISSN 1980-7791.

RIGO, Mônica Giusti. Meio ambiente igualitário: análise da relação entre a justiça equitativa de Rawls e o princípio da "não-regressão" de Michel Prieur. Revista Eletrônica Direito e Política, Programa de Pós-Graduação Stricto Sensu em Ciência Jurídica da UNIVALI, Itajaí, v.10, n.1, edição especial de 2015. Disponível em: www.univali.br/direitoepolitica, acesso em 15 abr2021

SARLET, Ingo Wolfgang. A eficácia dos direitos fundamentais: Uma teoria geral dos direitos fundamentais na perspectiva constitucional. $10^{a}$ edição, revista, atualizada e ampliada. Ed. Livraria do Advogado. Porto Alegre, 2010, p. 284.

SCHIRATO, Maria Aparecida Rhein. NOVO normal: entenda melhor esse conceito e seu impacto em nossas vidas (07/05/2020). Disponível na internet em: <https://www.insper.edu.br/noticias/novo-normal-conceito/>. Acesso em 19 abr2021.

SILVEIRA, Francisco Secaf Alves. A concretização do Direito Financeiro: Os efeitos do contingenciamento na execução orçamentária. Dissertação em Direito Financeiro. Universidade de São Paulo - USP. 2014.

SOUZA JUNIOR, Jarbas Paula de. Responsabilidade civil do Estado em tempos de COVID-19: breves considerações a luz das recomendações da Organização Mundial da Saúde e sob a ótica constitucional moderna dos Direitos e Garantias Fundamentais. Revista Eletrônica Direito e Política, Programa de PósGraduação Stricto Sensu em Ciência Jurídica da UNIVALI, Itajaí, v.15, n.3, $3^{\circ}$ quadrimestre de 2020. Disponível em: www.univali.br/direitoepolitica, Acesso em 12 abr2021

SUXBERGER, Antonio Henrique Graciano, LEMOS, Rubin. O orçamento público como instrumento de concretização da dignidade da pessoa humana. Revista Jurídica da Presidência Brasília, v. 22 n. 126 Fev./Maio 2020, p. 88-112.

TC 018.177/2020-4, Processo das Contas do Governo de responsabilidade do Presidente da República Jair Bolsonaro cujo parecer prévio foi da relatoria do Ministro Bruno Dantas, do TCU.

RECEBIDO EM: MAI/2021

APROVADO EM: JUL/2021 